\title{
DNA Oligonucleotide 3'-Phosphorylation by a DNA Enzyme
}

\author{
Alison J. Camden, Shannon M. Walsh, Sarah H. Suk, and Scott K. Silverman* \\ Department of Chemistry, University of Illinois at Urbana-Champaign, 600 South Mathews Avenue, \\ Urbana, Illinois 61801, United States
}

\section{Table of Contents}

Oligonucleotides. page $\mathrm{S} 2$

In vitro selection procedure page S2

Optimization of capture step for in vitro selection page S4

Selection progression page S5

Deoxyribozymes other than $3^{\prime} \mathrm{Kin} 1$ page S5

Comparison of capture reaction for $3^{\prime} \mathrm{Kin} 1$ phosphorylation product and standard. page S6

Additional data for metal ion dependence of $3^{\prime} \mathrm{Kin} 1$ page S6

Data for RNA substrate tolerance of $3^{\prime} \mathrm{Kin} 1$ page $\mathrm{S} 7$

Additional data for substrate sequence tolerance of $3^{\prime} \mathrm{Kin} 1$ page $\mathrm{S} 7$

References for Supporting Information page $\mathrm{S} 8$ 


\section{Oligonucleotides}

DNA oligonucleotides were obtained from Integrated DNA Technologies (Coralville, IA) or prepared by solid-phase synthesis on an ABI 394 instrument using reagents from Glen Research. 5'-Triphosphorylated RNA (pppRNA) oligonucleotides were prepared by in vitro transcription using synthetic DNA templates and T7 RNA polymerase. ${ }^{1,2}$ All oligonucleotides were purified by $7 \mathrm{M}$ urea denaturing PAGE with running buffer $1 \times$ TBE ( $89 \mathrm{mM}$ each Tris and boric acid and $2 \mathrm{mM}$ EDTA, pH 8.3) as described previously. ${ }^{3,4}$

\section{$\underline{\text { In vitro selection procedure }}$}

The selection procedure, cloning, and initial analysis of individual clones were performed essentially as described previously, ${ }^{3,5}$ but with a different ligation step $^{6,7}$ and with a capture step involving EDCmediated 3'-phosphorimidazolide formation and subsequent attack of a 5 '-amino capture oligonucleotide. ${ }^{6}$ An overview of the key selection and capture steps of each round is shown in Figure 2, and a depiction with nucleotide details is shown in Figure S2.

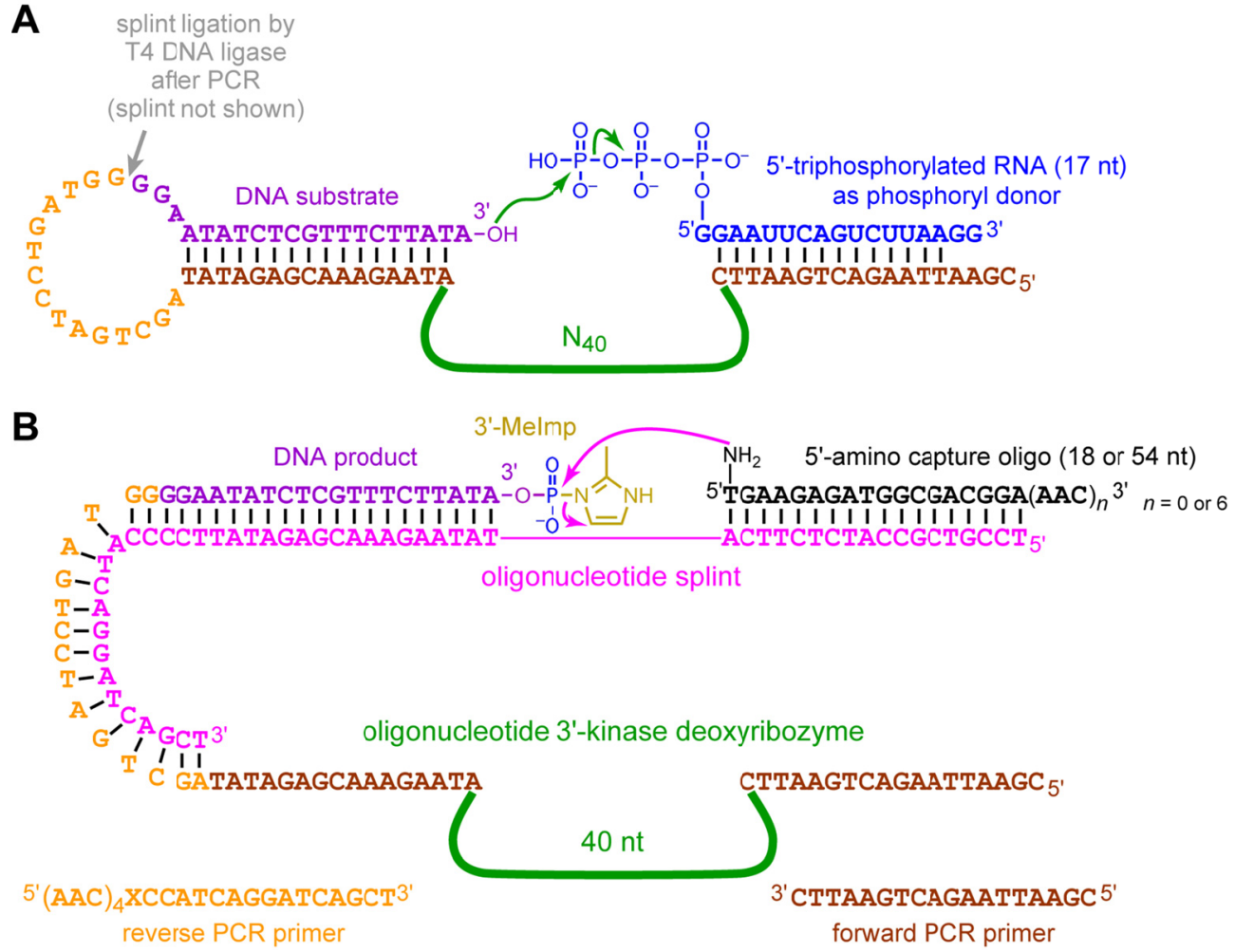

Figure S1. Nucleotide details of the selection and capture steps of in vitro selection. (A) Selection step. (B) Capture step, showing 2-methylimidazole/EDC-activated 3'-MeImp on the DNA product reacting with 5'-amino capture oligonucleotide. To avoid emergence of noncatalytic DNA sequences that migrate aberrantly at a fixed PAGE position, the length of the $5^{\prime}$-amino capture oligo was alternated in successive rounds between a short version (18 nt, even-numbered rounds) and a long version (54 nt, odd-numbered rounds including round 1). Also shown are the two PCR primers that are used following the capture step. In the reverse PCR primer, $\mathrm{X}$ is the HEG spacer (Glen Spacer 18) that stops extension by Taq polymerase and leads to a size difference between the two PCR product strands.

Procedure for ligation step in round 1 . The splint sequence was 5'-ATAAGAAACGAGATATTCCCCATCAGGATCAGCTATATCTCGTTTCTTAT-3'. A $35 \mu \mathrm{L}$ sample containing 800 pmol of DNA pool, 900 pmol of DNA splint, and $1 \mathrm{nmol}$ of $5^{\prime}$-phosphorylated DNA substrate was annealed in $5 \mathrm{mM}$ Tris, $\mathrm{pH} 7.5,15 \mathrm{mM}$ $\mathrm{NaCl}$, and $0.1 \mathrm{mM}$ EDTA by heating at $95{ }^{\circ} \mathrm{C}$ for $3 \mathrm{~min}$ and cooling on ice for $5 \mathrm{~min}$. To this solution was added $4 \mu \mathrm{L}$ of $10 \times$ T4 DNA ligase buffer ( $400 \mathrm{mM}$ Tris, $\mathrm{pH} 7.8,100 \mathrm{mM} \mathrm{MgCl} 2,100 \mathrm{mM}$ DTT and 5 $\mathrm{mM}$ ATP) and $1 \mu \mathrm{L}$ of $5 \mathrm{U} / \mu \mathrm{L}$ T4 DNA ligase (Fermentas). The sample was incubated at $37{ }^{\circ} \mathrm{C}$ for $12 \mathrm{~h}$ and separated by $8 \%$ PAGE. 
Procedure for ligation step in subsequent rounds. The same splint was used as in the round 1 ligation procedure. A $17 \mu \mathrm{L}$ sample containing the PCR-amplified DNA pool ( 5-10 pmol), 50 pmol of DNA splint, and 100 pmol of 5'-phosphorylated DNA substrate was annealed in $5 \mathrm{mM}$ Tris, pH 7.5, $15 \mathrm{mM}$ $\mathrm{NaCl}$, and $0.1 \mathrm{mM}$ EDTA by heating at $95^{\circ} \mathrm{C}$ for $3 \mathrm{~min}$ and cooling on ice for $5 \mathrm{~min}$. To this solution was added $2 \mu \mathrm{L}$ of $10 \times$ T4 DNA ligase buffer and $1 \mu \mathrm{L}$ of $1 \mathrm{U} / \mu \mathrm{L}$ T4 DNA ligase (Fermentas). The sample was incubated at $37^{\circ} \mathrm{C}$ for $12 \mathrm{~h}$ and separated by $8 \%$ PAGE.

Procedure for selection step in round 1. Each selection experiment was initiated with $200 \mathrm{pmol}$ of the ligated pool. A $20 \mu \mathrm{L}$ sample containing 200 pmol of ligated pool and 300 pmol of 17 nt pppRNA phosphoryl donor was annealed in $5 \mathrm{mM}$ HEPES, $\mathrm{pH} 7.5,15 \mathrm{mM} \mathrm{NaCl}$, and $0.1 \mathrm{mM}$ EDTA by heating at $95^{\circ} \mathrm{C}$ for $3 \mathrm{~min}$ and cooling on ice for $5 \mathrm{~min}$. The selection reaction was initiated by bringing the sample to $40 \mu \mathrm{L}$ total volume containing $70 \mathrm{mM}$ HEPES, $\mathrm{pH} 7.5,1 \mathrm{mM} \mathrm{ZnCl}_{2}, 20 \mathrm{mM} \mathrm{MnCl}_{2}, 40 \mathrm{mM} \mathrm{MgCl}$, and $150 \mathrm{mM} \mathrm{NaCl}$. The $\mathrm{Mn}^{2+}$ was added from a $10 \times$ stock solution containing $200 \mathrm{mM} \mathrm{MnCl} 2$. The $\mathrm{Zn}^{2+}$ was added from a $10 \times$ stock solution containing $10 \mathrm{mM} \mathrm{ZnCl}_{2}, 20 \mathrm{mM} \mathrm{HNO}_{3}$, and $200 \mathrm{mM} \mathrm{HEPES}$ at pH 7.5; this stock solution was freshly prepared from a $100 \times$ stock of $100 \mathrm{mM} \mathrm{ZnCl} 2$ in $200 \mathrm{mM} \mathrm{HNO}_{3}$. The metal ion stocks were added last to the final sample. The sample was incubated at $37{ }^{\circ} \mathrm{C}$ for $14 \mathrm{~h}$ and separated by $8 \%$ PAGE.

Procedure for selection step in subsequent rounds. A $10 \mu \mathrm{L}$ sample containing the ligated pool and 50

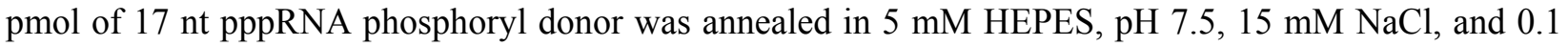
$\mathrm{mM}$ EDTA by heating at $95{ }^{\circ} \mathrm{C}$ for $3 \mathrm{~min}$ and cooling on ice for $5 \mathrm{~min}$. The selection reaction was initiated by bringing the sample to $20 \mu \mathrm{L}$ total volume containing $70 \mathrm{mM} \mathrm{HEPES,} \mathrm{pH} 7.5,1 \mathrm{mM} \mathrm{ZnCl}{ }_{2}$, $20 \mathrm{mM} \mathrm{MnCl}_{2}, 40 \mathrm{mM} \mathrm{MgCl}$, and $150 \mathrm{mM} \mathrm{NaCl}$. The sample was incubated at $37{ }^{\circ} \mathrm{C}$ for $14 \mathrm{~h}$ and separated by $8 \%$ PAGE.

Procedure for capture step in round 1. A $40 \mu \mathrm{L}$ sample containing ligated pool, $300 \mathrm{pmol}$ of capture splint, 400 pmol of 5'-amino capture oligonucleotide (54 nt), $50 \mathrm{mM}$ HEPES, pH 7.5, $150 \mathrm{mM} \mathrm{NaCl}, 100$ $\mathrm{mM}$ EDC (added from a freshly prepared $1 \mathrm{M}$ stock solution), and $100 \mathrm{mM}$ 2-methylimidazole (added last from a $1 \mathrm{M}$ stock solution) was incubated at $55^{\circ} \mathrm{C}$ for $2 \mathrm{~h}$. The sample was separated by $8 \%$ PAGE.

Procedure for capture step in subsequent rounds. A $20 \mu \mathrm{L}$ sample containing ligated pool, $25 \mathrm{pmol}$ of capture splint, $50 \mathrm{pmol}$ of 5'-amino capture oligonucleotide (18 nt in even rounds; $54 \mathrm{nt}$ in odd rounds), 50 $\mathrm{mM}$ HEPES, $\mathrm{pH} 7.5,150 \mathrm{mM} \mathrm{NaCl}, 100 \mathrm{mM}$ EDC (added from a freshly prepared $1 \mathrm{M}$ stock solution), and $100 \mathrm{mM}$ 2-methylimidazole (added last from a $1 \mathrm{M}$ stock solution) was incubated at $55^{\circ} \mathrm{C}$ for $2 \mathrm{~h}$. The sample was separated by $8 \%$ PAGE.

Procedure for PCR in subsequent rounds. In each selection round, two PCR reactions were performed, 10-cycle PCR followed by 30-cycle PCR. First, a $100 \mu \mathrm{L}$ sample was prepared containing the PAGE-separated capture product, 200 pmol of forward primer, $50 \mathrm{pmol}$ of reverse primer, $20 \mathrm{nmol}$ of each dNTP, $10 \mu \mathrm{L}$ of $10 \times$ polymerase buffer $\left(200 \mathrm{mM}\right.$ Tris- $\mathrm{HCl}, \mathrm{pH} 8.8,100 \mathrm{mM}\left(\mathrm{NH}_{4}\right)_{2} \mathrm{SO}_{4}, 100 \mathrm{mM}$ $\mathrm{KCl}, 20 \mathrm{mM} \mathrm{MgSO}_{4}$, and 1\% Triton X-100), and Pfu polymerase. This sample was cycled 10 times according to the following PCR program: $94{ }^{\circ} \mathrm{C}$ for $2 \mathrm{~min}, 10 \times\left(94{ }^{\circ} \mathrm{C}\right.$ for $30 \mathrm{~s}, 47^{\circ} \mathrm{C}$ for $30 \mathrm{~s}, 72{ }^{\circ} \mathrm{C}$ for $30 \mathrm{~s}), 72{ }^{\circ} \mathrm{C}$ for $5 \mathrm{~min}$. Pfu polymerase was removed by phenol/chloroform extraction. Second, a $50 \mu \mathrm{L}$ sample was prepared containing $1 \mu \mathrm{L}$ of the 10-cycle PCR product, $100 \mathrm{pmol}$ of forward primer, $25 \mathrm{pmol}$ of reverse primer, $10 \mathrm{nmol}$ of each dNTP, $20 \mu \mathrm{Ci}$ of $\alpha{ }^{32} \mathrm{P}$-dCTP $(800 \mathrm{Ci} / \mathrm{mmol}), 5 \mu \mathrm{L}$ of $10 \times$ polymerase buffer, and Pfu polymerase. This sample was cycled 30 times according to the following PCR program: 94 ${ }^{\circ} \mathrm{C}$ for $2 \mathrm{~min}, 30 \times\left(94{ }^{\circ} \mathrm{C}\right.$ for $30 \mathrm{~s}, 47^{\circ} \mathrm{C}$ for $30 \mathrm{~s}, 72{ }^{\circ} \mathrm{C}$ for $\left.30 \mathrm{~s}\right), 72{ }^{\circ} \mathrm{C}$ for $5 \mathrm{~min}$. Samples were separated by $8 \%$ PAGE. 
Procedure for cloning and initial screening. Using $1 \mu \mathrm{L}$ of a 1:1000 dilution of the 10-cycle PCR product from selection round 12, 30-cycle PCR was performed using the above procedure, omitting $\alpha-{ }^{32} \mathrm{P}-$ dCTP and using primers 5'-CGAATTAAGACTGAATTC-3' (forward primer, 25 pmol) and 5'-TAATTAATTAATTACCCATCAGGATCAGCT-3' (reverse primer, 25 pmol), where the extensions with TAA stop codons in each frame were included to suppress false negatives in blue-white screening. ${ }^{8}$ The PCR product was purified on $2 \%$ agarose and cloned using a TOPO TA cloning kit (Invitrogen). Miniprep DNA samples derived from individual $E$. coli colonies were assayed by digestion with EcoRI to ascertain the presence of the expected inserts. Using the miniprep DNA samples, PCR (same conditions as 30-cycle PCR during selection, omitting $\alpha_{-}{ }^{32} \mathrm{P}-\mathrm{dCTP}$ ) was performed to obtain the deoxyribozymes. Half of the PCR product was used to perform screening assays. Each screening assay used $\sim 0.05 \mathrm{pmol}$ of $5^{\prime}{ }^{32} \mathrm{P}$-radiolabeled DNA substrate, 100 pmol of pppRNA phosphoryl donor, $\sim 20$ pmol of deoxyribozyme and the single-turnover assay procedure described in a subsequent section of this document.

\section{Optimization of capture step for in vitro selection}

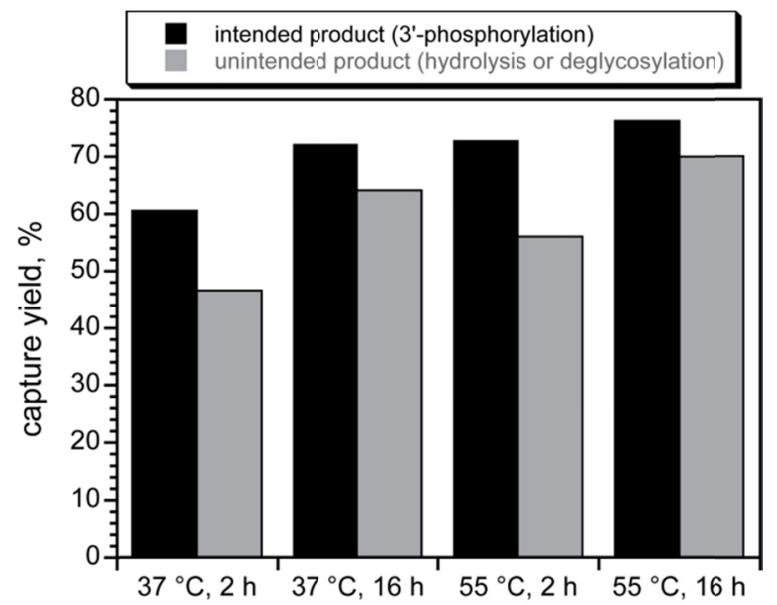

Figure S2. The capture step was optimized in the Figure S1B arrangement, with either the intended 3'-phosphorylation product (DNA product ...TATAp-3') or the unintended product from either hydrolysis or deglycosylation one nucleotide to the $5^{\prime}$-side (DNA product ...TATp-3'). Incubation conditions: $50 \mathrm{mM}$ HEPES, $\mathrm{pH}$ $7.5,150 \mathrm{mM} \mathrm{NaCl}, 100 \mathrm{mM} \mathrm{EDC}$, and $100 \mathrm{mM}$ 2-methylimidazole at either $37^{\circ} \mathrm{C}$ or $55^{\circ} \mathrm{C}$ for either $2 \mathrm{~h}$ or $16 \mathrm{~h}$. Robust capture of the intended $3^{\prime}$-phosphorylation product was observed under all four conditions (black bars); unfortunately, little difference relative to capture of the unintended product was observed (grey bars). In the selection experiments, $55^{\circ} \mathrm{C}$ for $2 \mathrm{~h}$ was used for all capture steps. 


\section{Selection progression}

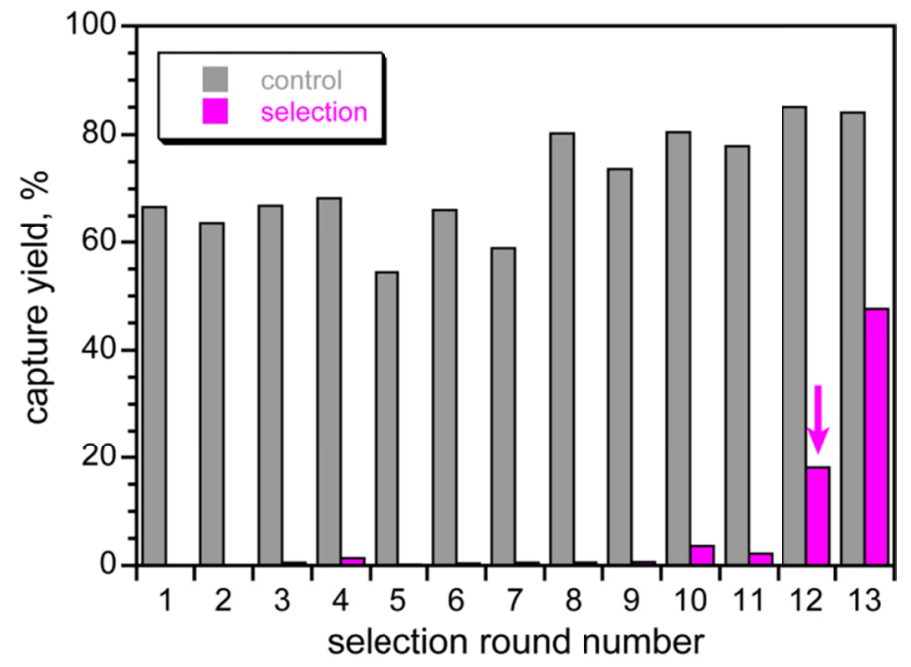

Figure S3. Progression of the in vitro selection experiment. In each round, "control" refers to the yield for the capture reaction using a 3'-phosphorylated substrate standard, and "selection" refers to the yield for the capture reaction using the deoxyribozyme pool for that round. Individual deoxyribozymes were cloned from round 12, as marked with an arrow.

\section{Deoxyribozymes other than $3^{\prime} \mathrm{Kin} 1$}

In addition to 3'-Kin1, four other deoxyribozymes were identified from round 12 of the selection experiment. All four deoxyribozymes appear to catalyze formation of a product that is missing two nucleotides from the DNA substrate's 3'-terminus and has a 3'-phosphate (Figure S4A). This product could be formed by either of two mechanisms that cannot be distinguished on the basis of the product identity alone. These two mechanisms are direct DNA-catalyzed hydrolysis of the phosphodiester bond ${ }^{9-11}$ or deglycosylation of the nucleotide (T) immediately to the 3'-side of the bond that is broken followed by two elimination reactions. ${ }^{12,13}$ The sequences of the four other deoxyribozymes are unrelated to each other and to 3'-Kin1 (Figure S4B).

A

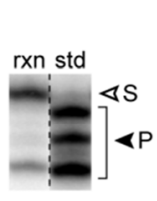

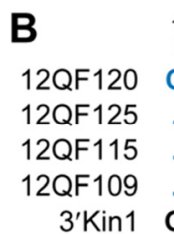$$
\begin{aligned}
& 1 \\
& \text { C } \\
& \text { G } \\
& \text { G }
\end{aligned}
$$

TACCAGGAAG

GGG A..G.A.G.T

G GC. A. . AGT

AGGAGTA.T. CGGA. TCGCC AGCGAGC AT
30

CCATCCGTGA TCAAGTTGTC

TA...G..C. C. CAA.CCG

. AGCTG.A.G G. TGTAGCGG

. ACAGGCACG GGG.T.A.G.

Figure S4. Additional deoxyribozymes identified from the selection experiment. (A) Representative PAGE analysis of the 12QF115 deoxyribozyme $(t=16 \mathrm{~h})$, which is one of the four additional deoxyribozymes other than $3^{\prime} \mathrm{Kin} 1$. S marks the 20-mer DNA substrate; P marks three actual or potential products. The standard ladder of $3^{\prime}$-phosphorylated oligonucleotides includes, top to bottom, $5^{\prime}$-...TATAp-3' (i.e., full-length DNA substrate with added $3^{\prime}$-phosphate), 5'-..TATp-3', and 5'-..TAp-3'. (B) Sequences of the initially random regions of the deoxyribozymes. All deoxyribozymes other than $3^{\prime}$ Kinl were used as $5^{\prime}$-CCTTAAGACTGAATTC-N 40 -ATAAGAAACGAGATAT-3', where $\mathrm{N}_{40}$ represents the specific 40 nucleotides of the initially random region as determined through the selection process. The alignment shows only the initially random region. A dot denotes conservation, i.e., the same nucleotide as in the uppermost sequence. Each deoxyribozyme is listed with its internal laboratory designation such as $12 \mathrm{QF} 120$, where 12 is the round number, QF1 is the systematic alphabetical designation for the particular selection, and 20 is the clone number. $3^{\prime} \mathrm{Kin} 1$ is shown at the bottom of the alignment for comparison. 
Comparison of capture reaction for 3'Kin 1 phosphorylation product and standard

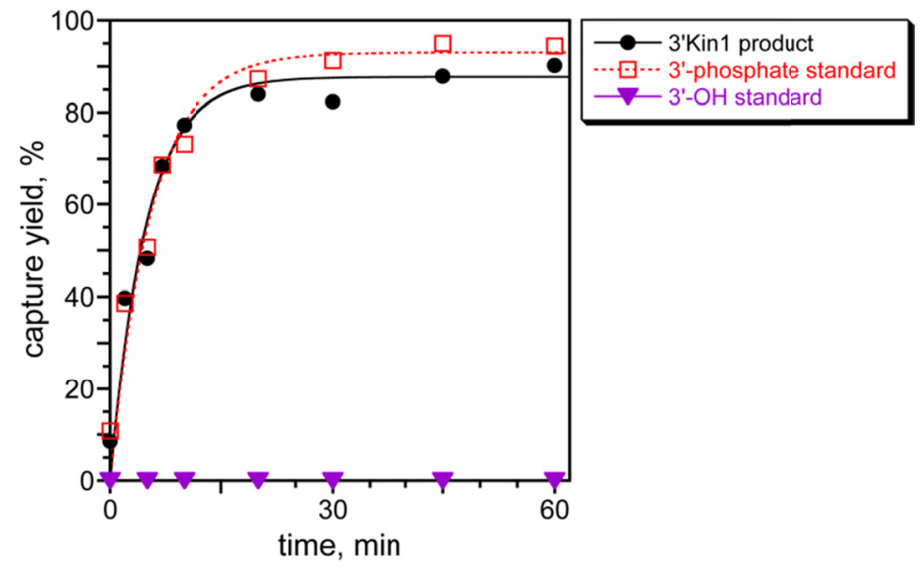

Figure S5. Validation that the $3^{\prime} \mathrm{Kin} 1$ phosphorylation product is captured via splint ligation with equivalent rate constant and yield as the $3^{\prime}$-phosphorylated oligonucleotide standard. The same capture procedure as implemented during in vitro selection was used here. $k_{\mathrm{obs}}$ values: $3^{\prime} \mathrm{Kin} 1$ product $0.20 \mathrm{~min}^{-1} ; 3^{\prime}$-phosphorylated standard 0.18 $\min ^{-1}$.

Additional data for metal ion dependence of 3'Kin1

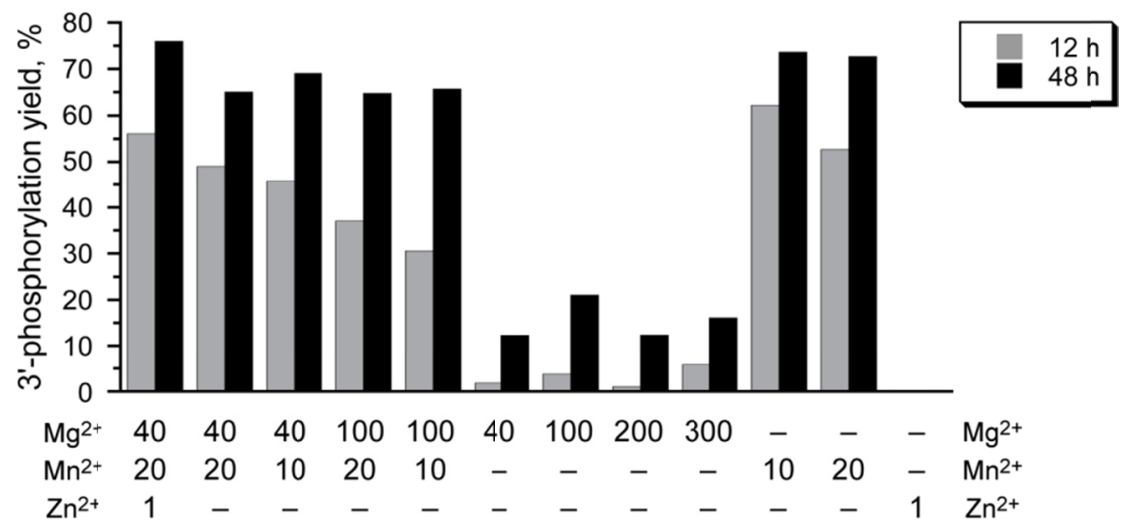

Figure S6. Additional data for metal ion dependence of 3'Kin1. Incubation conditions were $70 \mathrm{mM}$ HEPES, pH 7.5, combinations of $\mathrm{ZnCl}_{2}, \mathrm{MnCl}_{2}$, and $\mathrm{MgCl}_{2}$ at the indicated concentration $(\mathrm{mM})$, and $150 \mathrm{mM} \mathrm{NaCl}$ at $37^{\circ} \mathrm{C}$. 
Data for RNA substrate tolerance of 3'Kin1

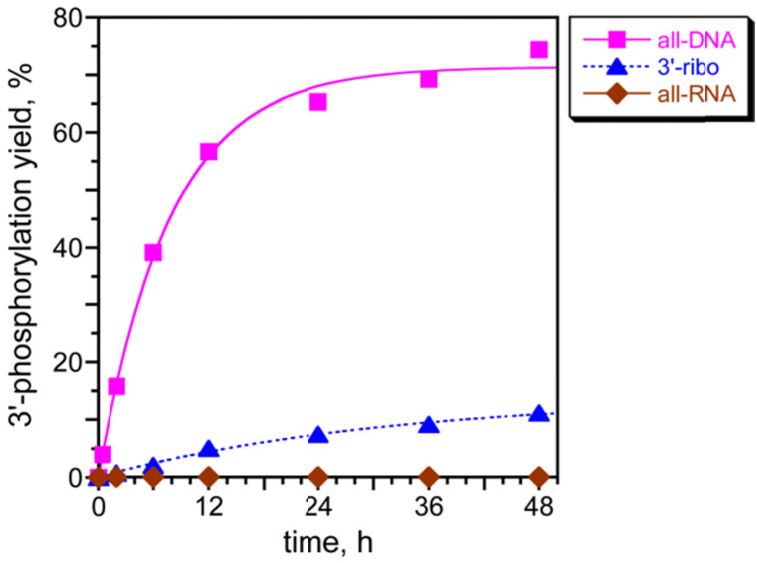

Figure S7. Data for RNA substrate tolerance of 3'Kin1. The deoxyribozyme with the fixed-sequence T mutation was used. The substrate was either all-DNA, all-DNA except for a 3'-terminal ribonucleotide, or all-RNA. Incubation conditions were $70 \mathrm{mM}$ HEPES, $\mathrm{pH} 7.5,1 \mathrm{mM} \mathrm{ZnCl}_{2}, 20 \mathrm{mM} \mathrm{MnCl}_{2}, 40 \mathrm{mM} \mathrm{MgCl}_{2}$, and $150 \mathrm{mM} \mathrm{NaCl}$ at $37^{\circ} \mathrm{C}$. $k_{\text {obs }}$ values: all-DNA substrate $0.13 \mathrm{~h}^{-1}$ and $3^{\prime}$-ribo substrate $0.032 \mathrm{~h}^{-1}$.

Additional data for substrate sequence tolerance of $3^{\prime} \mathrm{Kin} 1$

Table S1 summarizes 3'-phosphorylation yields for various combinations of the 3'Kin1 deoxyribozyme and its DNA substrate. With the exception of 3'-GG, all 5'-NKR-3' sequences at the substrate 3'terminus are $3^{\prime}$-phosphorylated with substantial yield that is highest with $\mathrm{T}$ at the first fixed-sequence 3'Kin 1 nucleotide immediately to the $3^{\prime}$-side of the initially random region (yellow-shaded boxes in Table S1; also see Figure 4). Three other substrates that do not follow the $5^{\prime}$-NKR-3' motif also have $>10 \%$ yield with one of the $3^{\prime}$ Kin1 nucleotide options (pink-shaded boxes in Table S1).

DNA substrate 3 '-terminus

\begin{tabular}{|c|c|c|c|c|c|c|c|c|c|c|c|c|c|c|c|c|}
\hline & $\mathrm{TA}$ & $\mathrm{TT}$ & $\mathrm{TC}$ & TG & $\mathrm{AA}$ & $\mathrm{AT}$ & $\mathrm{AC}$ & $A G$ & $\mathrm{CA}$ & $\mathrm{CT}$ & $\mathrm{CC}$ & CG & GA & GT & GC & GG \\
\hline $\mathrm{T}$ & 71 & 2 & 1 & 55 & 18 & 0 & 0 & 2 & 8 & 1 & 3 & 9 & 62 & 12 & 1 & 38 \\
\hline A & 35 & 0 & 1 & 10 & 6 & & & & 13 & & & & 9 & & & \\
\hline C & 74 & & & & 5 & & & & 4 & & & & 4 & & & \\
\hline G & 62 & & & & 2 & & & & 3 & & & 1 & 42 & 4 & 1 & \\
\hline
\end{tabular}

Table S1. 3'-Phosphorylation yields for the 3'Kin1 deoxyribozyme ( $t=48 \mathrm{~h}$ under single-turnover assay conditions; an empty box denotes combination not tested). For $3^{\prime} \operatorname{Kin} 1$, the indicated nucleotide is at the position highlighted yellow in Figure 2, potentially able to interact with the penultimate nucleotide of the DNA substrate. For the DNA substrate, the indicated two nucleotides are at the 3'-terminus; the first of these is highlighted grey in Figure 2. 
References for Supporting Information

(1) Milligan, J. F.; Groebe, D. R.; Witherell, G. W.; Uhlenbeck, O. C. Oligoribonucleotide synthesis using T7 RNA polymerase and synthetic DNA templates. Nucleic Acids Res. 1987, 15, 8783-8798.

(2) Milligan, J. F.; Uhlenbeck, O. C. Synthesis of small RNAs using T7 RNA polymerase. Methods Enzymol. 1989, 180, 51-62.

(3) Flynn-Charlebois, A.; Wang, Y.; Prior, T. K.; Rashid, I.; Hoadley, K. A.; Coppins, R. L.; Wolf, A. C.; Silverman, S. K. Deoxyribozymes with 2'-5' RNA Ligase Activity. J. Am. Chem. Soc. 2003, 125, 2444-2454.

(4) Wang, Y.; Silverman, S. K. Characterization of Deoxyribozymes That Synthesize Branched RNA. Biochemistry 2003, 42, 15252-15263.

(5) Kost, D. M.; Gerdt, J. P.; Pradeepkumar, P. I.; Silverman, S. K. Controlling regioselectivity and siteselectivity in RNA ligation by $\mathrm{Zn}^{2+}$-dependent deoxyribozymes that use 2',3'-cyclic phosphate RNA substrates. Org. Biomol. Chem. 2008, 6, 4391-4398.

(6) Sachdeva, A.; Chandra, M.; Chandrasekar, J.; Silverman, S. K. Covalent Tagging of Phosphorylated Peptides by Phosphate-Specific Deoxyribozymes. ChemBioChem 2012, 13, 654-657.

(7) Chandrasekar, J.; Silverman, S. K. Catalytic DNA with Phosphatase Activity. Proc. Natl. Acad. Sci. USA 2013, 110, 5315-5320.

(8) Langner, J.; Klussmann, S. PCR primers containing stop codons reduce the number of falsenegatives during blue-white screening. BioTechniques 2003, 34, 950-954.

(9) Chandra, M.; Sachdeva, A.; Silverman, S. K. DNA-catalyzed sequence-specific hydrolysis of DNA. Nat. Chem. Biol. 2009, 5, 718-720.

(10) Xiao, Y.; Wehrmann, R. J.; Ibrahim, N. A.; Silverman, S. K. Establishing Broad Generality of DNA Catalysts for Site-Specific Hydrolysis of Single-Stranded DNA. Nucleic Acids Res. 2012, 40, 17781786.

(11) Gu, H.; Furukawa, K.; Weinberg, Z.; Berenson, D. F.; Breaker, R. R. Small, highly active DNAs that hydrolyze DNA. J. Am. Chem. Soc. 2013, 135, 9121-9129.

(12) Sheppard, T. L.; Ordoukhanian, P.; Joyce, G. F. A DNA enzyme with $N$-glycosylase activity. Proc. Natl. Acad. Sci. USA 2000, 97, 7802-7807.

(13) Dokukin, V.; Silverman, S. K. Lanthanide Ions as Required Cofactors for DNA Catalysts. Chem. Sci. 2012, 3, 1707-1714. 